\title{
YOUNG PEOPLE IN MISSION
}

Mihai Himcinschi*

\begin{abstract}
The Church was always preoccupied by the importance of the mission with the young people. This contact starts in the ecclesial environment and is sustained by the religious education in school, while the family becomes the common denominator of these two promoting directions of life into Christ. The religious education, in Church or school, brings more value to the consciousness of the young people preoccupied with spirituality and a balanced life. Christ is their model, a model that is pretty relative in the new mediatic culture that centres the life outside the Life. Rich in dogmatic content, the missionary teaching of the Church tries to use the new and modern methods of a communicative education according to the understanding and the interest of the new generations of young people. The new mediatic agora may be a missionary environment, available for a spiritual teaching and not for a publicist controversy where religion is treated as a secular ethics.Our young people could have important lessons to learn if the Church, through its mission, would preach the benchmarks of a Christian life more than an empty morality lacking the perspective.
\end{abstract}

Keywords: mission, young people, Church, communication, spirituality, media, internet, fundamentalism.

\section{The young people - between a type and a prototype}

For the young people, the teachings of the Saviour and His miracles are analysed from a perspective of a visible and palpable concrete world. The necessity to see with the eyes of the faith becomes an existential imperative for the quotidian ontology. This explains the immediate desire for a model of holiness to be followed, descending to the incapacity of the human nature, to the measure of juvenile thinking, a dedicated friend for all interpersonal relations.

As Son of the embodied Lord, Jesus Christ Our Saviour is the most capable to satisfy the aspirations of the young people in their

\footnotetext{
* PhD Rev Professor, Dean of Faculty of Orthodox Theology at University “1 Decembrie 1918" in Alba Iulia.
} 
religious research and exploration and the perfect model is His human divine nature. Only reflecting upon the human nature in Christ, we may discover the real significance from a proto typological perspective offered to the young Christian generations. The Son of God became human, body and we saw the face of the perfect model in the light of the grace and truth (John 1:14), through the fulfilling of the palpable concrete (John 2:11).

The relation between the young people and Christ has an iconological fundament from the above mentioned perspective. The mystery of the face, the visual palpability, is not just a prerogative of the missionary thinking at the beginning of the $3^{\text {rd }}$ millennium but has apostolic origins, too: which we have seen with our eyes, which we have looked upon...declare we unto you (1 John 1:1, 3). This is the single manner to overcome the secular objectivism and the reiteration of the dialogical dimension, because the apophatic aspect of the personal existence may be discovered only face-to-face with the transcendental trinitarian reality.

"A superior power irradiates through the words and the face of any person, due to the spirit. If the world was created through the word, it is in exchange transformed through the light of the eyes God dresses up with because its substance is made after the face of the substance in the resurrected body". ${ }^{1}$

The young people are destined to know the Saviour, ab initio, in His historical reality. This discovery gives them the knowledge of life, the teachings and the His reality of Son of God and unique Saviour. The soteriological questions start from here. The biblical rich young man (Matthew 19:16) started from the historical reality of meeting God as Word and developed it under a spiritual dimension.

1 Dumitru Stăniloae, Teologia Dogmatică Ortodoxă, vol. III, București, Edit. Institutului Biblic și de Misiune al Bisericii Ortodoxe Române (EIBMBOR), 1978, p. 388. 
"A specific question was emitted for God Our Saviour. Life was questioned about life, Saviour was questioned about salvation, the Teacher was questioned about one of His most important teachings, the Truth about the real immortality; the Word was asked about The Word of the Father, the Perfection was asked about the perfect peace, Immortality was asked about immortality"'.

Such a young man is always a beloved disciple (John 13:23), a type in the search of his prototype. This effort is a missionary one opening the human face to the Face of God and the two faces start to communicate, to receive power and light to restore the human icon continuously oscillating between revelation and idolatry, although the simplicity of faith always conquers the demonstrations of rationality always put in the balance.

The worship to the causal things shifts us off the Prototype. Choosing a way of life related to the offers of the mediatic consumerism distorts the essence of life. Most of the time, the depletion of vital energy at a young age leads to the asthenia of the mature and old ages, due to the secular way of living. Any pure immanent circumscription is autonomous when it is not looking or not reaching to the resemblance with the transcendent archetype. Choosing a perfect model in life, the young people will search for the circumscription through body in Christ, not toward His divine nature not part of any circumscription. This Model is perfect for all the people of all ages.

"Because he became human after being God, because any man is a prototype of His icon and no man may exist without being a copy of His iconic representation, it is obvious that Christ, becoming like us

${ }^{2}$ Sfântul Clement Alexandrinul, Care bogat se va mântui?, translated by pr. D. Fecioru, București, EIBMBOR, 1982, p. 38. 
under all aspects, is a prototype of His icon, even this is not written expressis verbis" 3 .

We must look at the promises from the pages of the Old Testament with the eyes of the faith: the temple, the blight, the copper serpent etc. They are fulfilled in the New Testament: the body on the cross, the Eucharist, the cross as symbol of victory. Jesus Christ manifests as Son of God, the personal expression of the Father (John 14:9), The Way, The Truth and The Life (John 14:6) because we may reach the Father only through Christ (John 14:6). It is necessary to have faith, but is also necessary to have a contemplative look: to see Christ where it might seem that $\mathrm{He}$ is not there. Those still not finding Christ should ask to the believers the evangelic hortative: we want to see Jesus (John 12:21). Seeing (contemplative and mystical) Christ is the fundament of the evangelisation (1 John 1:1-3) because the mission, especially related to the young people, is achieved communicating the not testamentary experience of Jesus ${ }^{4}$.

\section{With the young people inside the pastoral communication}

In its missionary activity, the Church is accused by a society full of dynamism that does not have the means for an efficient communication in the public space, especially with the young people. The ecclesial language is considered to be old and not innovative, with an insufficient expressivity under the formal and informal aspect. Thus, the preaching for the young people, as aspect of the daily mission for the young generations, imperatively requires a renewal of the communicational education.

${ }^{3}$ Sfântul Teodor Studitul, Iisus Hristos Prototip al icoanei Sale, translated by Diac. Ioan I. Ică jr., Alba Iulia, Editura Deisis, Sfầnta Mănăstire Ioan Botezătorul, 1994, p. 98.

4 Juan Esquerda Bifet, Giovanni evangelista, in "Dizionario dell'Evangelizzazione", Napoli, Editrice Domenicana Italiana, 2005, p. 387-388. 
The world is in a rapid change. The sources of communication are some very modern and rapid. The priority question may be asked as follows: may the new media culture include the evangelisation of the young people using other methods and not the classical ones?

The contemporaneity is profoundly marked by the idea of an ecclesial sacred. The holiness is linked only to a specific place, a complete permission manifesting outside the restrictive sphere. This is the perception of the young people on various levels of the media culture in the globalised society. For them, the new models, predominant in communication, oscillate between the anthropocentrism and values and the general religiosity. This perspective lacks the maturity of a Christ centred life, where the Word of God becomes our word and the dialogical communication receives new dimensions and perspectives for an eschatological opening:

"For as the rain cometh down, and the snow from heaven, and returneth not thither, but watereth the earth, and maketh it bring forth and bud, that it may give seed to the sower, and bread to the eater: So shall my word be that goeth forth out of my mouth: it shall not return unto me void, but it shall accomplish that which I please, and it shall prosper in the thing whereto I sent it" (Isaiah 10:11).

In the same degree the direct of communication through the word is old, revealed and soteriological, the new communication through media is optional, impersonal and insufficient, useful but unsatisfying the need of absolute. In the vision of the last type of communication, the rationality wonders unfulfilled, between optimism and pessimism, waiting anxiously the time of a future change with the regret of the lost time. "The travel starts through ecclesial maturity when it comes to multimedia communication, a travel that progressively suffered and had a condemned discernment even from the start". 5

${ }^{5}$ André Joos, Muoversi pastoralmente nella comunicazione e comunicativamente nella pastorale, in "Pastorale della comunicatione. Evangelizzazione e nuova cultura dei media", Roma, Urbaniana University Press, 2004, p. 3. 
The preaching of communication in general and especially related to the young people is a new concept in the field of the mission. It is linked to the feeling of human plenitude, as a response to the modern secular factor of humanisation that makes possible any dialogue. In their nature, the humans open to dialogue, searching for a communication network, whose absence might lead to ontological poverty. As a paradox, searching for a rich communicational relation into the virtual space, the young man finds a regress of the knowledge between humans, anonymity instead of identity affirmation, a disappointment of unfulfilled dreams instead a perseverance built on the pattern of a much desired reality.

In its mission, the Church must relaunch in the media the notions of person and human community as palpable perspectives of the immediate human experience. "I know my human value only directly and without intervention contact with the fellow people in the daily proximity. As essence: the person id authentically a multimedia person through distance". The people would not be willing to communicate without the distance between them, would not feel the desire of complementarity through the others. The sin distances the people and the more makes them feel more isolated, the more they make impressive efforts to communicate easier, more rapid and cheaper.

The multimedia preaching, from distance, is not an immediate missionary success, but only an instrumental extension of this type of mission, appearing as a limited closed fact, encircled and autonomous, out of the field of the classic ecclesial missionaries. Its fruits may not be immediately measured and they are not visible because they it addresses to a topographic and local proximity that is limited. Acknowledging these limits, the Church is forced to come back to the classic biblical preaching methods of the Word in a direct dialogue with the young people through direct meetings, with visible, immediate and commensurable results. In spite of all its characters of new era of communications, the provocation of the direct dialogical word in the

${ }^{6}$ Ibidem. 
contemporary society has all the chances to be in the top of the various modalities of modern communicative preaching.

Although the young people communicate very intense, the poverty of the evangelic Word in the virtual space is more and more visible. The religious value of the sacred is eclipsed the autonomous affirmation of the immanent axiology. Adults, young people and adolescents, sunk in an aggressive multimedia communication, live in an environment that excludes the transcendence, the only condition that could offer the plenitude of the complete value in achieving the human condition. The predominant orientations of the contemporary society aim to guide the young people in three directions: pleasure, ambition and winning. The recent observations show that in our secular society, delimited by aspects of Christian eschatological aspects, the centre of the spiritual life is given by quantity, visibility and tangibility.

The young man is a person open to communication (Matthew 19:16) and this leads to the communicational necessity of a human being who is very dynamic at this age. "This faculty is manifested in a complex experience of exteriorisation. An individual may be communicative only in the degree he manages to combine thinking and action". ${ }^{7}$ The pastoral communication with the young people has as starting point the person as source of knowledge. Only the person gives value to the existence because is always open to the other, where finds the same fulfilling and identity. The human being, as a living soul (Genesis 2:7) is solicited by Him to answer the divine call. No matter the modality of communication, the man does not lost the divine print, in spite the sophisticated level of social, cultural, spiritual and moral paradigm of the era we are living in, the loss means sadness (atymia, Greek), disregard for the real, not transitory, unfailing human value. The disregard for the world and the human fellows maintains a tension in the soul that leads to depression.

${ }^{7}$ Claudio Pighin, Pastorale della comunicatione. Evangelizzazione e nuova cultura dei media, Roma, Urbaniana University Press, 2004, p. 9. 
The continuous battle against discourage and the problem of the juvenile suffering, even if they seem external, are similar to the young nun Olimpiada in the times of Saint John.

"Olimpiada's problem is a psychological one. The writings of John show that she knew it in a lucid way, even she was assisting to its aggravation. Olimpiada suffered of athymia, a psycho-somatic disease caused by sadness and discouragement, leading to an irreversible state of depression" 8 .

Athymia $^{9}$, translated through discouragement, more and more often met to the young people nowadays,

"is compared with the most horrible disease, a worm, rust, a torturer, a storm, a tyrant, and the night. Sometimes is a cloud, sometimes is an ash covering the soul. The soul abandoning to it is kept captive stronger than in an armour. The Christian theology teaches that there are a good sadness and a bad sadness. For a Christian, losing the measure and abandoning to sadness, abandoning without control even to a legitimate suffering, a new gravity exists. The Christian permits the work of the devil when abandoning to sadness. It is not an error the human commits in front of an ideal harmony, it is an alliance made with the evil forces against God. Athymia is not just a disease that breaks a vigorous soul, it

${ }^{8}$ Ioan Ică jr., Diaconița și arhiepiscopul, in Sfântul Ioan Gură de Aur, Scrisori, in "Cuvioasa Olimpiada diaconița. O viață, o prietenie, o corespondență", translated by Ioan Ică jr., Sibiu, Edit. Deisis, 1997, p. 20.

9 ,Sadness (athymia) is an oven for the tournament of the souls, an unspeakable pain, and a punishment more bitterly than any other. Sadness imitates a poisonous worm that bites from the body and the soul; a moth consuming the house and the mind; a torturer that does not rip the bones, but diminishes the power of the soul; a forever night, complete darkness, storm, agitation, unseen cold that burn more than a flame; a war that does not lose its weapons, a disease that blinds those blind. The sun and the clear sky seem to embarrass those filled with sadness; midday is for them just a dark night", in Sfântul Ioan Gură de Aur, Scrisori, in "Cuvioasa Olimpiada diaconița. O viață, o prietenie, o corespondență", translated by Ioan Ică jr., Sibiu, Edit. Deisis, 1997, p. 142. 
also plays an important role in the mysterious action Satan does in the world and it is his most powerful help, in the end a big $\sin ^{10}$.

The vigour of youth is undermined by the sins without discernment. The young man, without a consistent experience in the mysteries of life, does not immediately succeeds in his actions and this brings him sadness without any limit, putting in danger the entire being: body and soul. "The tyranny of sadness (athymias) pushes hard, ... to make you search for comfort without limit in it and to make the sanity of your soul forever hurt"11.

The risk is enormous. The young man tries to exit the pain of pleasure through another pleasure and the sinful circuity is endless. Sadness has no cure but Christ, the Lamb that abolishes the humans suffering from Adam until the end of time. The Pascal joy takes the place of sadness, life replaces death, the fallen nature is restored by the resurrected Saviour and the Holy Face of Resurrected Christ takes the place of sinful imagination (Luke 24:5-11). "Instead of doing everything to dissipate the sadness, alone you run to painful thoughts and imagine things that don't exist - they are just your words - and you suffer without use and for the worst" $"$.
"After erasing from the mind the memory of all the pain causes by sadness, have complete and stable peace and lot of joy. I do not intend only to make you let the sadness go, but to fill your soul with much continuous joy. It is possible if you want it. Joy does not depend on the rules of nature, not possible to change or stop, it depends on our free will, we may easily manipulate...the joy does not reside in the nature of things, but in the will of the people"13.

\footnotetext{
${ }^{10}$ Anne-Marie Malingrey, O viață, o prietenie, o corespondență, in Sfântul Ioan Gură de Aur, Scrisori, in "Cuvioasa Olimpiada diaconița. O viață, o prietenie, o corespondență", translated by Ioan Ică jr., Sibiu, Edit. Deisis, 1997, p. 53-54.

${ }^{11}$ Sfântul Ioan Gură de Aur, Scrisoarea VIII, in "Cuvioasa Olimpiada diaconița.

O viață, o prietenie, o corespondență", translated by Ioan Ică jr., Sibiu, Edit. Deisis, 1997, p. 114.

12 Ibidem, p. 134.

${ }^{13}$ Ibidem, p. 141.
} 
"Sadness makes you sick"14. "Once you manage to let sadness go, you manage to let disease go; if you grab the root, you also destroy the branches; if the branches stay strong and green, bringing bad fruits, I cannot be convinced you grabbed the root". ${ }^{15}$

\section{The young people in the new mediatic areopagus}

How may a young man communicate in an efficient manner in the society of the new mediatic areopagus? He must possess exigently the quality to distinct the values and dissolve the unrepresentative. In the middle of the mediatic ambiance, more and more perfectionist, there is the risk of transmitting a precarious message, to disregard the value of the human being without reaching its real philosophy of redemption, in our case the message of the Embodied Word, the only one to give meaning to the human ontology.

Preaching communication will go, through the young people, toward an organic discourse: theocentric, Christ centred and ecclesial. "In a world where the horizon leads to a Babylonian confusion, the preaching message must find a language where the image and the science (of communication) should be clear, courageous, preoccupied of all the consistency". ${ }^{16}$

The audio-visual world functions after the rule of the plenary humanism, a virtual game related to the human being, its value and destiny. Per se, the preaching communication is a filter, not a recipient. Thus, it is eliminated the risk of formatting an addressee for a unidirectional and authoritative communication. The internet, e.g., presenting itself as the big liberator, cannot offer this filter. No network present the sign of any value hierarchy, all are equal: the groups, the competences and the communities, the axiological pyramid do not function there anymore.

\footnotetext{
${ }^{14}$ Ibidem, p. 179.

${ }^{15}$ Ibidem, p. 185.

${ }^{16}$ Claudio Pighin, op. cit., p. 9.
} 
The experience of communicating via internet is the last, from a temporal perspective, to involve the contemporary human being. We are already in a digital era and this influences, unfortunately, in a determinant manner the thinking process of the humans. Thinking in a digital manner means to reflect to a mode that is perfect and exact, rapid and fix, but with no limits, intensifying through virtuality the information of the favourite offers. From this point of view, the ideal, for the human being, is to thing digitally and act analogically. From theological and psychological perspectives, we underline that the analogic thinking may not be generated without the interpersonal contact and without the experience of the relations, feelings and rational actions of the human being.

The phenomenon of the digital trend has a universal dimension and is especially interesting for the young generation and the middle age generation. We are talking about a communication that generates an attractive force, even a fascinating one, because it has the possibility to create contacts, information and relations with persons at the distance, to direct to sites and, a serious fact, to produce virtual realities.

In its missionary function, the Church ask us to equally assume this way of communication and convert it into an on line evangelisation instrument. In order to achieve it, sometimes being a re-evangelisation, we must re-evaluate the immediate missionary imperatives, as: multiple ethnicities, multiple religiosity and multiculturalism. Starting with these missionary challenges, the Church is urgently called to respond using the modern ways of mass communication and developing a preaching communication received especially by the young people as frequent users.

There are three positions related to this proposal: indifference, integration and critique. For those indifferent to the new missionarypastoral method, the Church brings the same application considered old but sustainable by conservators, to the level of congregations, catechetical schools and pastoral. Those integrating the new modern evangelisation methods are all ears to the messages from the virtual 
space belonging or related to the Church. The new missionary reality fascinates them, but there is the risk of creating virtual ecclesial communities, religious social networks tending to substitute the real liturgical cult. In the on line environment, the personal interest becomes a group interest and the points of view are expressed free and rapidly. This is a positive aspect. The critiques of the method and its medium and long term effects consider that evangelisation may not be separated from the real ecclesial environment and the liturgical sinaxis. This type of communication, apparently liberal and participative, always ends in impersonal and anti-personal dependence. The on line technology is exclusivist on the way of the humans to the Kingdom.

"The internet is the great liberator (?!). There is no hierarchy in network. In fact, the main preoccupation of the network is to become a community of competencies. Due to this characteristic of the electronic world, we understand the promotion in the real world as a traditional pyramidal structure, not only a functional one, while the continuous evolution in the capacity of various groups (networks), based on the need of the client, function perfectly. Is the Church aware of this change? Will the church be willing to discern and perfect the alternative structure with more flexibility, interaction and opening?"17

Still, we have to admit that the internet and its network offer the occasion, in a progressive expansion, to create a continuous exchange with the possibility to achieve immediate knowledge, scientific collection of data and behavioural VIP patterns. The approach pro catalogued the preoccupation as internet culture, very successful for the young people. The Church must admit that the internet is a channel of social communication and the main mass informative instrument to individual, familial and social levels. If the internet is or not a gift of god, if the Gospel must adapt to this new mass communicational

${ }^{17}$ Colin Saldanha, Chiesa e internet, in "Gen's rivista di vita ecclesiale", 4/5 (2000), p. 135-136. 
paradigm $^{18}$, remains for the Church to certify or not the effects in the missionary space, especially when it comes to young people. Such analyse is pertinent only due to the fact that this type of juvenile culture is the horizon of the present world and part of the providential history of God. "It is a history that may be approached from a point of view specific to the communication, related to various aspects of the contemporary practice... and we know that it is part from a type of acculturalisation where the destiny of the human being is at stake". ${ }^{19}$

The typology of the contemporary human society is the group, not the person. The humans are seen in the context of the mass where they live their imaginary universe. The anonymity, the depersonalisation, the technological slavery, the pan-economical ideology and the loss of identity are only a few of the objectives proposed by the secular doctrine. The network communication represents a psychological, sociologic, cultural, and educational and in the same time a pastoral-missionary phenomenon that determines the spirituality of the young people, in the middle of their process of forming a character. We all live in communicational system that is the post-industrial type, characteristic for the present times. We are all in front of the communicative reality which is vital for the humanity and consists of an abundance of knowledge and the fruits of a technical progress amazing us more and more each day.

\section{The young people and the religious fundamentalism}

Although not perceived in the contemporary society, the manifestation of the religious fundamentalism has its theological explanation based on the tangential point between the religious indifference and the over abundant offer of religious beliefs and ideas as supermarket type culture. The lack of a spiritual balance, of a ghostly authority may generate fundamentalist attitudes and

\footnotetext{
${ }_{18}$ Angela Ann Zukowski, The changing of paradigm, in "The pastoral planning of social Communication", UNDA-OCIC (Eds.), Montreal, EP, 1998, p. 59.

${ }^{19}$ Claudio Pighin, op. cit., p. 22.
} 
manifestations. The fundamentalist conception of the religious experience aims to be an effective response to the secular phenomenon, disturbing in its hostile attitude toward God. There is no evangelical ground, but the fundamentalism answers to hostility with hostility. We believe that, in the future, could be interesting a theological debate upon the answer of the religious fundamentalism to the secular challenge of a so-called humanism that regenerates the base of communism in many Orthodox countries in the Eastern Europe.

\begin{abstract}
"We all use the plural - fundamentalists. Still, there is only one in the interior of the religious frame - the Islamic fundamentalism, concentrating the present preoccupations and especially the attention of the media. In fact, a fundamentalist tendency may be identified inside all the religious ambitions. In other words, we may say that from the fundamentalist attitude, with its capacity of highlighting and lead to the extreme some aspects of the religious experience, results a certain characteristic of religion in general" 20 .
\end{abstract}

In Church, the pillar and the ground of the truth (1Timothy $3: 15)$, the ideas and the beliefs of its members are defended from the centrifugal tendencies and the fundamentalist exaggerations at least for two reasons: there is no manipulation and the ecclesial theology is a theology of love through humility. Vita ecclesiastica is the conformity of the human nature with the reason it was created for, for divinity as internal reason, not for an external manipulative ideology. Still, there is a meaning of the adjective fundamentalist that requires discussion. It results from a latter extension of the noun fundamentalism, as attitude and mentality that comes to expose the human ambitions more than the spiritual characteristics. Fundamentalist is a more laic, rigid and unilateral term requiring a complete explanation related to the relation between human and divine. The tendency is a totalitarian one and leads us to the sad memory of the communist regime, to intolerance and exclusion. "The fundamentalist does not feel the necessity for dialogue

20 Adriano Fabris, I fondamentalism religiosi, in "Filosofia delle religioni", Carocci editore, Roma, 2012, p. 21. 
- a real dialogue...the fundamentalist mentality is highlighted through a partial and limited conception of one's own identity and represents a pathological nature, which comes to hurt the relational attitude between the humans" ${ }^{21}$.

Various types of fundamentalism come from various types of religious ambitions, as well from the various positions of the sociologists, psychologists and historians of religion. It is very hard to establish a common base between various types of fundamentalism. ${ }^{22}$ Still, we may identify, in generally, two typologies: legalist - literalist and charismatic-utopian. The first is more related to the past, to the meaning of the human life as a sacred test in the literally interpretation of the sacred texts. The second typology may be identified as a feature with an eschatological character, belonging to the future, where the believers may be led and where the fundamentalists have the role of creating sensibility under the menace of the end of times. They are, nowadays, the guarantee of the future of messengers and guides of a message that is reached based on a self-revealed charisma that becomes a testament for the community. They are the heroes, the saints and the messengers of the other land; the attitude of disregard for the present is given by their antisocial and negative relation with the content of the human daily life.

"In reality, the two types of fundamentalism are almost never met in pure form, but intertwine in their tradition. Related to this aspect, the philosophical study, unlike the sociology, is not just explained in a detailed work, but searching for the cause, identifying the reason. At the core of the fundamentalism there is the same attitude that comes to provoke in some kind of reporting to a present rejected due to its religious plurality" 23 .

${ }^{21}$ Ibidem, p. 22.

22 See Dr. Harriet A. Harris, Fundamentalism and Evangelicals, Oxford University Press, 2008.

${ }^{23}$ Adriano Fabris, op. cit., p. 23. 
Not only has the religious plurality provoked fundamentalist tendencies. An important role is played by secularism through the proliferation of the religious indifference. For the religious extremists, the anti-religious attitude is a reason to have a hostile attitude. More than this, there is no culture or spirituality to present value, tangential points of dialogue or possible marks of the natural revelation. Their God is not the God of the entire humanity. There is no message except that belonging to the unique leader asking for complete obedience as a result of an absolute perception of the sacred text in its word and spirit. Interculturality is not accepted and the same for any interethnic or interreligious dialogue.

"This brings a distinction between what should be done and what shouldn't be done, but, in order not to be a source of tensions, it does not offer the significance of the actions and ends in putting everything on the same direction, in a unique dimension. We may say that, without mentioning the significance of the religious offer, the meaning is hard to be understood". ${ }^{24}$

As any other mentality, the fundamentalism has a beginning, how was it born? Or: how was born this mentality that produces so much evil in the world? Which are its genesis and logics?

A possible response to these questions could send us to the observations upon the various religious contexts in the world and upon the way the sacred texts separated, although all referred in their essence to the same divinity. Each religion drew its image upon God, considered to be superior and imposed to others. In different religious environments, the behaviour was analogue through living, at an individual level, of the religious phenomena, beliefs and ideas. Each of them, through the religious etalon ambitions, were considered uniquely valid, legitimate and with juridical consequences in faith. This means that there is a single specific approach coming from the religious individual, there is a single experience of the divine with an absolute

${ }^{24}$ Ibidem, p. 23-24. 
validity and it must be considered normative for the entire human kind. Any other experience, any other approach is excluded and condemned.

Related to the origin and the stages of the fundamentalist mentality, we propose a synthesis in five points:

1. Only a practiced faith has a valid universal value;

2. The universal value may be, still, variable in concepts due to the religious human individual in his being;

3. An embodiment of a concrete and particular spiritual experience in the religious individual ends in losing the specific reference and becomes abstract, an absolute deity;

4. Becoming abstract, the fundamentalist religion merges with the personal identity, absorbing it and becoming its own Orthodoxy;

5. Faith becomes the only ideology absorbed at an individual level, profound, firm in a limited frame of a previous marked identity.

These are the stages that lead to the dynamics of the fundamentalist formation. They generate the mentality.

"From a general point of view, the fundamentalist mentality is configured now as pathology of thinking, some sort of particular contingent hypothesis, immediately circumscribed and considered valid by everyone, in a necessary and absolute manner. It always provokes, in an evident way, pathologically connects the world and the human being reporting to it and reconsiders its own identity in itself ${ }^{\prime 25}$.

What is specific to the religious fundamentalism is the degradation of the human experience to a personal level, an infamy to the address of the monotheist religions. The fundamentalist logics, under the religious aspect, is the one that makes a particular religion to gain, in short time, universal features and values, as the unique and exclusivist possibility of interpreting the unique relations between the religious individual and his God, a the God of his world and his human community. Its genesis depends on a particular, unilateral

${ }^{25}$ Ibidem, p. 23-25. 
understanding, on the relational form that may be established between the terms of identity and universality. We will have to pay a bigger attention in the future to the aspects of differentiation and exclusion, used more and more often in the fundamentalist environment and replaced with elements that unite and coagulate the postmodern society.

\section{Conclusions}

The role of the young people is important in our Church. Searching for a concrete model of living, the young people are overwhelmed by the divine human Model of our Saviour Jesus Christ. He is the solely concluding benchmark in a secular contemporary society.

Related to the mission among the young people, The Church is forced to change its pastoral discourse and its means to become credible. It is more and more circulating the idea of a new preaching of communication among the young generations.

The new mediatic culture is a provocation for the evangelic preaching. The new mediatic areopagus will be used as a good environment for the on line mission of the Church and the virtual space must receive Christ in order to become a missionary mean, we must not neglect the dependence from the IT sources, which creates depression and the objectification of the humans, hard to recuperate by psychologists, more often translated through the term of sadness.

The young people are predisposed to the extremist religious tendencies. Even if this tendency is not pregnant observable in the Christian environment, the Christians must be aware of the risks and the inconvenience of a wrong direction, even part of the spiritual, moral or religious environment.

\section{References}

1. Bifet, Juan Esquerda, Giovanni evangelista, in "Dizionario dell'Evangelizzazione", Napoli, Editrice Domenicana Italiana, 2005.

2. Fabris, Adriano, I fondamentalismireligiosi, in "Filosofia delle religioni", Carocci editore, Roma, 2012

3. Harris, Harriet, Fundamentalism and Evangelicals, Oxford University Press, 2008.

4. Ică, Ioan jr., Diaconița și arhiepiscopul, in "Sfầntul Ioan Gură de Aur. Cuvioasa Olimpiada diaconița. O viață, o prietenie, o corespondență", translated by Ioan Ică jr., Editura Deisis, Sibiu, 1997. 
5. Joos, André, Muoversi pastoralmente nella comunicazione e comunicativamente nella pastorale, in "Pastorale della comunicatione. Evangelizzazione e nuova cultura dei media", Roma, Urbaniana University Press, 2004.

6. Malingrey, Anne-Marie, $O$ viață, o prietenie, o corespondențăa, in "Sfântul Ioan Gură de Aur. Cuvioasa Olimpiada diaconița. O viață, o prietenie, o corespondență", translated by Ioan Ică jr., Editura Deisis, Sibiu, 1997.

7. Pighin, Claudio, Pastorale della comunicatione. Evangelizzazione e nuova cultura dei media, Roma, Urbaniana University Press, 2004.

8. Sfântul Clement Alexandrinul, Care bogat se va mântui?, translated by rev. D. Fecioru, București, Edit. IBMBOR, 1982.

9. Sfầntul Ioan Gură de Aur, Scrisori, in "Cuvioasa Olimpiada diaconița. O viață, o prietenie, o corespondență", translated by Ioan Ică jr., Editura Deisis, Sibiu, 1997.

10. Sfântul Teodor Studitul, Iisus Hristos Prototip al icoanei Sale, translated by Ioan I. Ică jr., Editura Deisis, Sfânta Mănăstire Ioan Botezătorul, Alba Iulia 1994.

11. Saldanha, Colin, Chiesa e internet, in "Gen's rivista di vita ecclesiale", $4 / 5$ (2000).

12. Stăniloae, Dumitru, Teologia Dogmatică Ortodoxă, , București, Edit. Institutului Biblic și de Misiune al Bisericii Ortodoxe Române (EIBMBOR), 1978.

13. Zukowski, Angela Ann, The changing of paradigm, in "The pastoral planning of social Communication", UNDA-OCIC (Eds.), Montreal, EP, 1998. 